
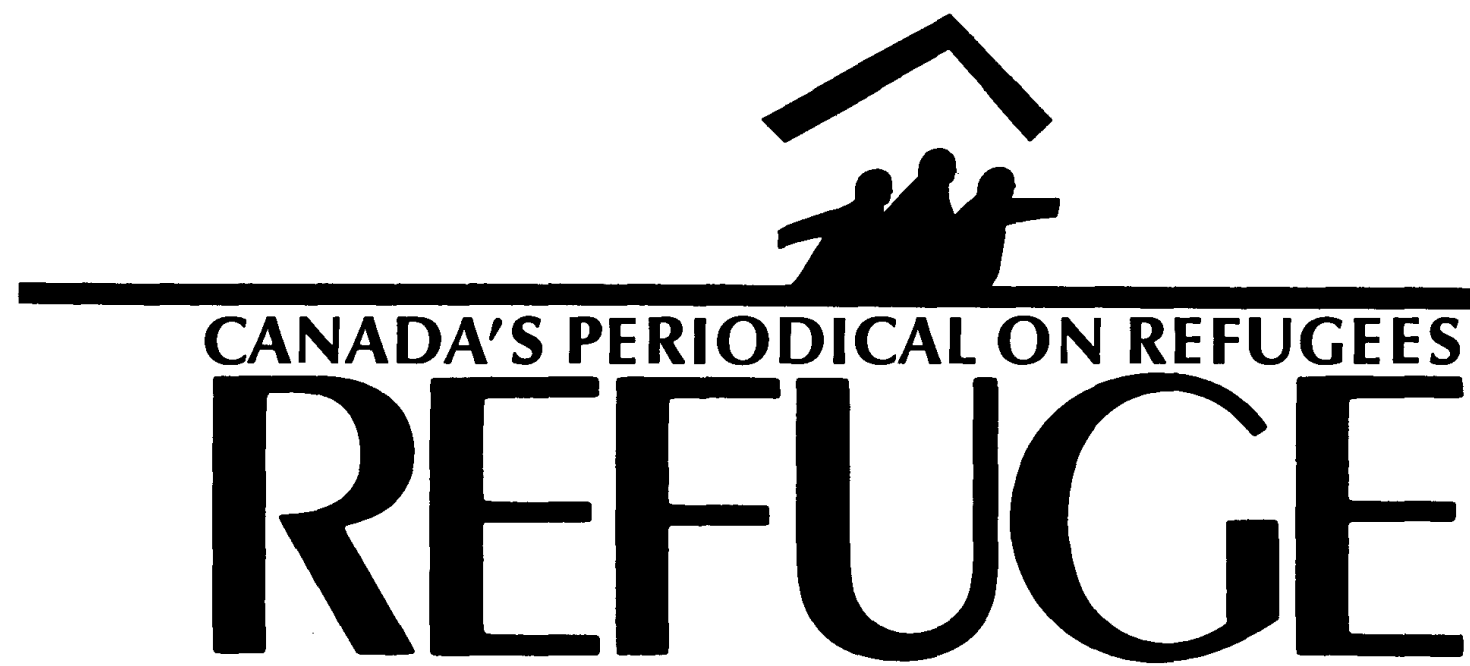

Vol. 8 , No. 4

June 1989

\title{
On Determination
}

When Christopher Wren designed his famous cathedral in London, the term "awful" was originally applied to the building. But in the original application, "awful" meant awe inspiring. Tastes changed. What was previously awe inspiring came to mean its opposite, "horrible". Is this the prospect for determination? Will the refugee determination system, developed originally to help and protect refugees, come to mean a system used to deter refugees and protect countries from the influx of spontaneous arrivals?

Determination is an equivocal term. It can refer to an attitude of resolve. It can be used as an adjective to refer to a process by which a decision is made. Unfortunately, a new meaning is starting to be attached to the term - a determined used of procedures to deter. In other words, instead of standing for a process of decision making, it begins to stand for a process which is aimed at deterring others from deciding, specifically deciding to escape their home countries and seek refugee status.
The article in this issue on the Hong Kong Refugee Determination system argues quite forcefully that this has, in fact, become the objective of the new refugee determination system in Hong Kong. The article reviewing the results of the first four months of the Canadian refugee determination system suggests that this has not been the result of the Canadian system, even if a case can be made that it may have been, to some degree, the strategy of the civil servants who developed and are still in charge of implementing the legislation. We have approximately the same number of successful refugee claimants as we had prior to the introduction of the new legislation, though we do not know if and how many genuine refugee have been deterred by the new system. Thus, in both cases we have determination systems designed to deter arrivals, but, in the case of Hong Kong, the arrivals keep coming even though there seems to be a total absence of objective determination in the system, while, in Canada, the arrivals have dropped significantly but the relative objectivity of the process has by and large been established.

Will "determination", when associated with refugees, come to develop a negative connotation associated with deterrence or will it retain a positive connotation associated with fair processing of claims?

Howard Adelman, Editor

\section{IN THIS ISSUE:}

The New Refugee System: Success or Failure? by Howard Adelman

An Opinion on UNHCR Involvement in Hong Kong by Simon Ripley

Canada and Immigration: Public Policy and Public Concern and Critical Years in Immigration: Canada and Australia Compared reviewed by Anthony $H$. Richmond

page 3

page 8

page 13 


\section{Boat People Returned to Haiti in Record Numbers}

In the first four months of 1989 (through April 25) 2,669 Haitians, risking their lives in overcrowded wooden sailboats in attempts to reach the United States, were stopped by the US Coast Guard and returned to Haiti.

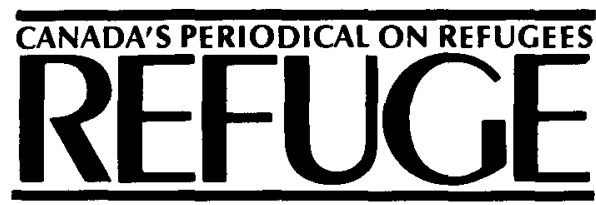

Centre for Relugee Studies, York University, Suhe 290J, Administrative Studies Building. 4700 Keele Street, North Yok, Ontario, Canada M3J 1 P3. Telephone: (416) 736-5663. Fax: (416) 736-5687. Electronic Mail Via Bitnet Address: REFUGE@YORKVM1.

\section{Editor: \\ Howard Adelman \\ Executive Editor: \\ Alex Zisman \\ Illustrations: \\ Herminio Ordóñez \\ Circulation Manager: \\ Helen Gross \\ Assistant to the Circulation Manager: Ching Man (C.M.) Wong}

Refuge is dedicated to the encouragement of assistance to refugees by providing a forum for sharing information and opinion on Canadian and international issues pertaining to refugees. It is published four times a year by the Centre for Refugee Studies. It is a non-profit, independent periodical supported by private donations and by subscriptions. It is a forum for discussion, and the views expressed do not necessarily reflect those of its funders or staff.

All materials in Refuge may be reproduced without permission unless copyrighted or otherwise indicated. Credit should be given to the author or source, if named.

Subscription rates for one year are $\$ 20.00$ in Canada and US $\$ 25.00$ overseas. Please enclose payment with your order.

Logo design:

Dreadnaught Co-operative Inc., Toronto Layout: PAGES plv'

Second Class Mail Registration N²5512 ISSN $0229-5113$
The month of March saw the greatest number interdicted since the operation began in 1981: 1,533 Haitians on 16 boats were forcibly repatriated. Twenty-three others drowned off the coast of eastern Cuba when their 40-foot sailboat, carrying a total of 166 people, capsized in heavy seas. [from Haitilnsight, Vol. 1, No. 1 (May 1989), p. 5]

\section{Immigration and Refugee Board Status of Claims}

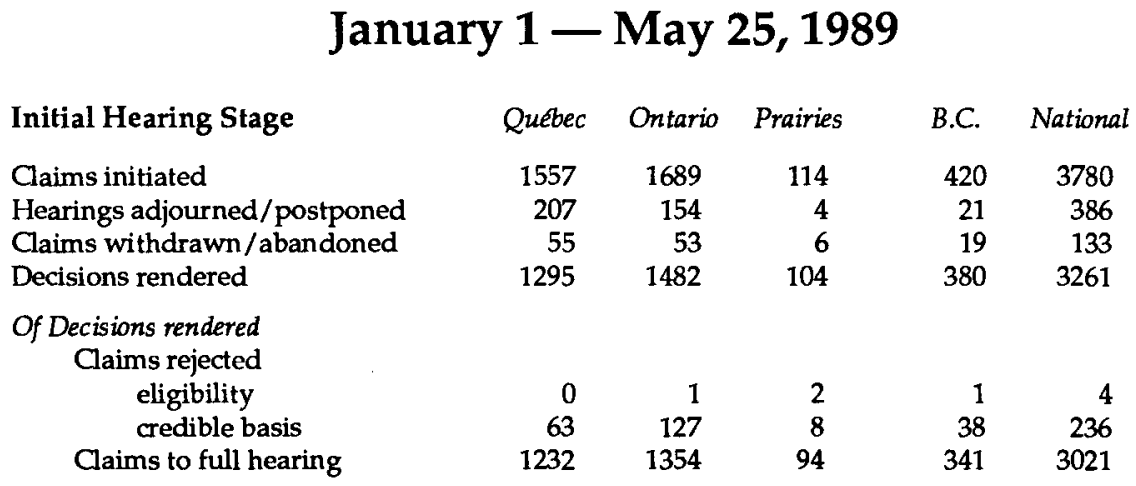

Initial Claims by Country of Alleged Persecution

$\begin{array}{lrlr}\text { Afghanistan } & 20 & \text { Iraq } & 73 \\ \text { South Africa } & 6 & \text { Jamaica } & 18 \\ \text { Argentina } & 38 & \text { Lebanon } & 450 \\ \text { Bangladesh } & 49 & \text { Nicaragua } & 46 \\ \text { Brazil } & 14 & \text { Pakistan } & 63 \\ \text { Chile } & 41 & \text { Panama } & 14 \\ \text { Peoples Republic of China } & 169 & \text { Peru } & 26 \\ \text { Colombia } & 12 & \text { Philippines } & 7 \\ \text { Costa Rica } & 5 & \text { Poland } & 149 \\ \text { El Salvador } & 276 & \text { Portugal } & 9 \\ \text { Ethiopia } & 37 & \text { Dominican Republic } & 1 \\ \text { Fiji } & 6 & \text { Somalia } & 415 \\ \text { Ghana } & 72 & \text { Sri Lanka } & 610 \\ \text { Guatemala } & 84 & \text { Syria } & 17 \\ \text { Guyana } & 11 & \text { Trinidad \& Tobago } & 26 \\ \text { Haiti } & 22 & \text { Turkey } & 3 \\ \text { Honduras } & 26 & \text { Venezuela } & 8 \\ \text { India } & 57 & \text { Zaire } & 29 \\ \text { Iran } & 345 & \text { Other } & 526\end{array}$

Full Hearing Stage

Claims initiated

Hearings adjourned/postponed

Claims withdrawn/abandoned

Decisions pending

Decisions rendered

Of Decisions rendered Claims rejected Claims upheld 